\title{
Criminal Investigation of Financial Crimes
}

\section{Keywords \\ Finance; Fraud; Embezzlement; Crime}

\begin{abstract}
Once the initial signs of financial fraud are detected, an investigation needs to be launched to determine its extent. The investigation should establish the facts that confirm the existence of financial crimes. This paper briefly describes what a criminal investigation of financial crimes should look like.
\end{abstract}

\section{Introduction}

Fraud evokes a visceral reaction in us [1]. It is an abuse of our expectation of fair treatment by fellow human beings. Beyond that, it is a blow to our self-image as savvy managers capable of deterring or detecting a fraudulent scheme. Whether we react because of our values or our vanity, nobody likes to be duped. Many elements of modern society are focused on maintaining an environment of fair dealing. Laws are passed; agencies are established to enforce them; police are hired; ethics and morals are taught in schools and learned in businesses; and criminals are punished by the forfeiture of their ill-gotten gains and personal liberty-all with a view to deterring, detecting, and punishing fraud. The profession of accounting and auditing grew out of society's need to ensure fair and correct dealings in commerce and government.

One of the central outcomes of fraud is financial loss. Therefore, in the minds of the investing public, the accounting and auditing profession is inextricably linked with fraud deterrence, fraud detection, and fraud investigation. This is true to such an extent that there are those whose perception of what can be realistically accomplished in an audit frequently exceeds the services that any accountant or auditor can deliver and, in terms of cost, exceeds what any business might be willing to pay. Public anger over occurrences of massive fraud in public corporations and the conduct of financial institutions has spawned substantial government spending, regulatory reform, global convergence of accounting standards, new auditing standards, new oversight of the accounting profession, and greater penalties for those who conspire to commit or conceal financial fraud or act corruptly.

Auditors are specialists in collecting, interpreting, and evaluating data and information [2]. Such skills are essential to forensic accounting. When forensic accountants testify before a trier of fact as an expert witness, they ordinarily express their findings as expert opinions. Their findings must be based on evidence, and evidence must be collected and interpreted. Therefore, forensic accountants should be skilled in collecting and interpreting evidence. Finally, forensic accounting requires knowledge and skills using specialized evidence gathering procedures.

\section{Financial Fraud}

Sad to say, human history and human nature tell a different story, and so do the statistics that examine them [3]. While most societies

\section{Journal of Forensic Investigation}

\author{
Franjić S* \\ Independent Researcher
}

*Address for Correspondence

Franjić S, Independent Researcher, Republic of Croatia,

Email: sinisa.franjic@gmail.com

Submission: 15 January, 2021

Accepted: 3 March, 2021

Published: 6 March, 2021

Copyright: ( $) 2021$ Franjić S, et al. This is an open access article distributed under the Creative Commons Attribution License, which permits unrestricted use, distribution, and reproduction in any medium, provided the original work is properly cited.

explicitly abhor violent crime and bodily harm, many societies hold financial fraud, whatever its scale, as a less reprehensible wrongdoing. Charles Ponzi, creator of the Ponzi scheme, was celebrated in some quarters as a folk hero and cheered by many of the people he helped to defraud. Financiers and executives, whose frauds can disrupt thousands or tens of thousands of lives, have historically been punished with relatively light sentences or serve their time at a lowsecurity federal "tennis camp." Some scholars have called this attitude toward white collar crime "a perversion of our general societal admiration for intelligence." With the advent of the Sarbanes-Oxley Act in 2002 and recent increases in prison terms for certain financial crimes, there is the expectation that this perception will change and white collar criminals will begin to endure what many would deem just punishment for their crimes.

During much of the past century, psychologists and sociologists struggled to understand the inner workings of people who commit white collar crime. Edwin Sutherland's White Collar Crime, the most influential work in the field, argued in 1939 that an individual's personality has no relevance to a propensity to commit such crimes. Rather, he said, economic crimes originate from the situations and social bonds within an organization, not from the biological and psychological characteristics of the individual. Sutherland also made the useful, if apparent, observation that criminality is not confined to the lower classes and to social misfits but extends, especially where financial fraud is concerned, to upper-class, socially well-adjusted people. Later authors introduced quite different ideas-for example, suggesting that financial fraud is an inevitable feature of capitalism, in which the culture of competition promotes and justifies the pursuit of material self-interest, often at the expense of others and even in violation of the law.

Fraud detection deals with activities and programs that detect frauds that have been committed [4]. Fraud detection mechanisms should be used on areas where preventive controls are weak or not cost effective. The summation and second-order tests are detection activities or detective controls.

In a continuous monitoring environment, internal auditors might need to evaluate data from a continuous stream of transactions, 
such as the sales made by an online retailer or an airline reservation system. Unpublished work suggests that the distribution of the differences (between successive transactions) should be stable over time. Consequently the digits of these differences should also be stable across time. Future research could address how the second-order test could be adapted so that it analyzes the differences between successive transactions. Research that shows potential benefits of continuously running the second-order tests on the differences between the (say) last 10,000 records of transactional data might be valuable. Such research could show what patterns might be expected under conditions of "in control" and "out of control."

The instant that an employee fraud matter surfaces, you must begin a continuous documentation of all pertinent actions [5]. Such documentation includes written narrative and pertinent hard copy with as much specificity as time permits. Its form can take many shapes, composed of handwritten notes, Microsoft Word files, emails to yourself, or almost any other method. This will, of course be time consuming but is another example of collateral damage resulting from employee fraud. The documentation should include reference to cost and expenses incurred because of the suspected fraud. Their documentation may permit them to be included as part of your insurance coverage or even within restitution. Other business damages, such as the loss of customers, suppliers, other employees, etc., may also merit documentation.

Document your knowledge of the suspect's personal actions and your perception of the suspect's behavioral factors. Such information may include your knowledge of the suspect's hobbies, travels, interests, etc. and can be helpful in prosecution. These details may also help explain their motivation to execute fraud. Law enforcement sometimes refers to such motivators as the "Three B's" that drive fraud. When discussing motive for male suspects, the paraphrase is "Booze, Bucks, or Broads." When discussing motive for female suspects, the paraphrase is "Booze, Bucks, or Boys." Within the context of the reference, Booze implies alcohol, drugs, or other addictive substances; Bucks implies gambling, excessive spending, and credit problems; Broads and Boys imply pornography, prostitution, and extramarital affairs. Therefore, even seemingly innocent behavior indicators may assist in restitution.

\section{Embezzlement}

Embezzlement is a low-profile crime that typically consists of employees of organizations stealing large amounts of money over a long period of time [6]. Embezzlement is also extremely difficult to detect. Those who are successful in the embezzling of funds can cause extensive fiscal damage to victim organizations, frequently resulting in their financial ruin.

A primary element of the crime of embezzlement is the element of trust. So, to investigate this type of crime, the investigator must show that the suspect first accepted the property in the scope of employment and then misappropriated it for his or her own use. Intent is relatively easy to demonstrate in these cases, however, because it usually requires some form of concealment or secrecy, such as altering business records. The investigation of embezzlement allegations is a tenacious and time-consuming task because paper trails are sometimes difficult to follow. Yet the investigator must be able to explain fully to a prosecutor, judge, and jury how the crime was committed and offer convincing evidence to support the findings of the case. This task can be especially perplexing when dealing with a company whose record-keeping practices are already haphazard.

Because many embezzlement cases require a degree of accounting expertise, investigators lacking such expertise may become frustrated, and the successful outcome of the case may then be jeopardized. The most common way of overcoming this obstacle is for the investigator to solicit the victim's help in providing technical support during the investigation. Company executives and consultants outside the company are generally willing and able to explain specific accounting processes. Embezzlers usually prefer to steal cash because it is both difficult to trace and easy to conceal. Investigators may, however, find this to be an advantage. For example, if an employee is found to be spending significantly large amounts of cash, he or she might also be hard-pressed to explain the origin of the money.

\section{Forensics}

Forensics are an integral part of criminal investigative practices and procedures [7]. Analysis of a crime scene provides the information and evidence necessary to determine the method used to commit the crime, the time and place the crime occurred, and the people involved in the crime. Forensics apply a wide range of scientific disciplines to determine the who, what, where, when, and how of the crime that was committed. Chemistry, biology, physics, anatomy, botany, and other disciplines are used to obtain any and all information possible about the crime. This, in turn, provides the best evidence possible for solving and prosecuting the perpetrators of the crime.

The world of business, finance, and economics also uses certain disciplines to accurately reflect financial transactions, transfer and ownership of property, and economic development. These disciplines include accounting, business law, trade and patent regulations, domestic and international tax laws, and commerce regulations. They rely on documentary evidence to support and reflect the financial transactions that occur in everyday life.

The skeptical mindset is something that has long been inherent in forensic accountants and other internal investigators when looking for evidence of fraud [8]. The investigator historically has asked a set of questions different from those of conventional auditor, who is monitoring the fnancial statements to see whether they are in compliance with generally accepted accounting principles (GAAP) and thereby fairly represent the fnancial conditions of the company. The process of forensic accounting is also sometimes more intuitive than deductive, although both intuition and deduction play important parts. Financial auditing is more procedural in many regards and is not intended to work as effectively as the tenets of fraud auditing and forensic accounting.

The performance of forensic audit procedures shall be a part of an audit of fnancial statements. There are several commonalities between financial statements' audit and forensic audit. Forensic thinking is used throughout the audit. To perform adequately the fraud detection procedures in an audit of fnancial statements, the forensic auditor must have or collect critical background information about the company, its business and its environment. In a sense, forensic audit procedures are more specifc as geared toward detecting the 
possible material misstatements in fnancial statements resulting from fraudulent activities or error.

Financial statement fraud normally leaves a trail that an alert reader can use to detect the fraud [9]. Unfortunately, that trail is often very muddled with immense amounts of information, most of which simply represents legitimate changes in a company's operations.

The challenge is to create a reliable set of procedures for detecting fraud in its earliest stages, starting with the use of fraud risk factors but also incorporating other techniques.

One of the most useful techniques for detecting fraudulent financial reporting is financial statement analysis.

\section{Investigators}

Forensic accounting investigators can make significant contributions to a financial crime investigation provided that they can work effectively with the company's internal and external auditors as well as with other constituents involved in resolving allegations or suspicions of fraud [10]. In addition to a thorough knowledge of accounting and auditing, the forensic accounting investigator brings to bear a variety of skills, including interviewing, data mining, and analysis. Some auditors assume that auditing more transactions, with the use of standard procedures, increases the likelihood that fraud will be found. While this can prove to be true in some cases, when there is suspicion of fraud the introduction of competent forensic accounting investigators may be more likely to resolve the issue.

Forensic accounting investigators work in a highly charged atmosphere and often present their findings in forums ranging from the boardroom and the courtroom to hearings before government agencies such as the U.S. Securities and Exchange Commission (SEC). Within the boundaries of an investigation, they typically deal with numerous constituencies, each with a different interest and each viewing the situation from a different perspective. These parties to the investigation may well attempt to influence the investigative process, favor their individual concerns, and react to events and findings in terms of individual biases. Forensic accounting investigators thus often have the task of conveying to all constituencies that the results of the investigation will be more reliable if all participants and interested parties work together and contribute their specific expertise or insight with truth-seeking objectivity. In the highly charged environment created by a financial crime investigation, the forensic accounting investigator usually bears much responsibility for displaying and encouraging levelheadedness.

\section{Investigation}

Because financial crimes incorporate planning, business acumen, and deception, they often take place over a long period of time before the effects are recognized [7]. There are two main reasons why detection of financial fraud takes a longer period of time. The first is that the plan for the fraud is designed to be concealed from the victim. The second is that financial crooks will usually start small and as time passes without detection they will be emboldened to take more and more. When the amounts of the financial fraud become greater, the victims will realize that something is wrong even if they do not know what it is or the perpetrators' gain will begin to appear way out of line with their legitimate earnings.
Due to the time frame involved, the investigator works on two aspects of the same crime: the effect of the crime in the past and the ongoing crime as it is occurring. This can cause difficulty in the presentation of the case. Just as business plans are modified to maximize profits, fraud schemes may be modified to increase illegal gains. Also, the laws may change over time and mitigate or accentuate the criminal activity. Therefore, the investigator needs to be able to present the logic and reasoning behind any modifications, and be alert to legal changes that may take place.

Gathering, documenting, and retaining evidence are crucial steps in any investigation and critical to forensic accounting investigations [11]. Decisions taken with respect to the gathering of evidence are intertwined with judgments about the scope and manner of investigation, and the value of the conclusions of an investigation ultimately rests on the credibility of the evidence discovered. Thus, care must be taken at all times to properly gather, preserve, store, and use evidentiary materials. Performed correctly, the means and manner of evidence gathering create a clear, straightforward, and convincing trail to the ultimate conclusions of the investigation. Conversely, laxity or error in the handling of evidentiary material may obscure the logic of an investigation and undercut its conclusions.

One should always begin an investigation as if the matter may end up in a criminal court, and for this reason take all appropriate steps to gather and preserve the evidence. Even if it is believed at the outset that it is unlikely the matter will be referred for prosecution, it is best to maintain that option. After all, one never knows where investigations may lead, and there may be no choice in the matter if an enforcement agency decides that the investigation is of interest.

In forensic accounting investigations, several types of evidence are normally relevant, and most of them are documentary in nature. Documents generally can be divided into broad categories: those that exist in electronic form or media and those that are physical in nature, such as paper documents. The two categories often overlap in that a document available in electronic form may have been printed and perhaps modified by notations placed on it by a recipient. Another type of evidence commonly encountered, indeed often critical to the success of forensic accounting investigations, is testimonial evidence of people who were involved in the matter. This generally takes the form of oral explanations offered to the investigative team and is reflective of either people's memory of events or their interpretation of documents containing information about the events under investigation. Gathering such evidence presents issues that differ from the collection of either electronic or physical documentary evidence.

\section{Evidence}

Evidence is anything that can be used to probe the events and identify the participants of a crime [12]. Investigators gather two types of evidence during an investigation, direct and circumstantial. Direct evidence refers to information gathered from statements made by a surviving victim, by suspects, and by eyewitnesses. This type of evidence, however, is notoriously unreliable. Perceptions of an event, as they pass from the eyes to the brain to the vocal chords, can be filtered and distorted in a number of ways. The accuracy of a person's account is subject to filtration by the witness' own visual acuity and is susceptible to distortion as it's refracted through the powerful lens 
of their bias, prejudice, and past experience. An eyewitness account is also vulnerable to flaws in continuity through the witness' own capacity, or lack thereof, for accurately remembering information and the order in which the events of the crime occurred.

\section{Expert Witness}

Lawyers, judges, and forensic accountants often view expert witnessing through different eyes [13]. A lawyer would like his client's expert witness to rebut the opposing expert, and to arrive at a conclusion favorable to his client. Judges often want the expert to arrive at a conclusion when the judge cannot reach one without the expert's assistance. There are times when more than one conclusion can be reached from the forensic facts available to the expert, but the judge wants the expert's facts and logic without a conclusion. This allows the judge to arrive at his own conclusion uncolored by opinions of the expert witness.

Forensic accounting experts have extensive experience in investigations to determine solutions to disputed accounting matters, to write expert reports on their investigation, and to appear in court as expert witnesses. The expert may be hired solely as a consultant to an attorney and his client during litigation, or as one who provides opinion evidence as an expert. Often, the roles of expert witness and expert consultant merge if so requested and arranged by the attorney on behalf of his client. The accounting expert witness should reach conclusions independent of the attorney and client who hired him even though they may arrive at similar conclusions. He must direct his written reports and oral testimony under oath to assist the trier of fact to arrive at valid conclusions in light of the accounting matters as applied to the law.

Expert witness accounting can be somewhat like politics. While the expert witness accountant must be independent of the parties to the dispute, he may conclude from the facts, and his interpretation of them, that his engaging attorney is correct and that the opposition is wrong. If he can demonstrate the proof of his conclusions, he is a strong expert witness.

Accounting often baffles nonaccountants, and, in its advanced theory, it also can baffle long-time accountants. Even the most skillful and experienced lawyer can misunderstand what the accountant is telling him. The accountant seems to speak in a different language. Even lawyers who are also certified public accountants (CPAs) but have not practiced public accounting, or have minimal accounting experience, often misunderstand accountants. Of course, judges and juries are not immune to confusion relative to accounting. The attorney must help the accounting expert witness to state his conclusions in terms that the attorney, the judge and the jury can understand.

\section{Conclusion}

When financial statements present financial results better than they actually are, this is, above all, falsified business documents. In this way, they try to cover up financial fraud and create an apparent picture of the situation. Such situations can lead to a serious threat to business, and sometimes even to the liquidation of economic entities.

\section{References}

1. Skalak SL, Alas MA, Sellitto G (2011) Fraud: An Introduction“ in Golden, TW Skalak, SL Clayton MM, Pill JS (eds): A Guide to Forensic Accounting Investigation, Second Edition“, Price water houseCoopers, John Wiley \& Sons, Inc., Hoboke, USA 1.

2. Crain MA; Hopwood H.S; Pacinni C, Young GR (2015) Essentials of Forensic Accounting“, American Institute of Certified Public Accountants, Inc., New York, USA 7 .

3. Golden TW (2011) Psychology of the Fraudster" in Golden, TW Skalak SL Clayton MM, Pill JS (eds): A Guide to Forensic Accounting Investigation, Second Edition“, PricewaterhouseCoopers, John Wiley \& Sons, Inc., Hoboke, USA 25-26.

4. Nigrini MJ (2012) Benford's Law - Applications for Forensic Accounting, Auditing, and Fraud Detection“ John Wiley \& Sons, Inc., Hoboken, USA 115.

5. Dorrell DD, Gadawski DA (2012) Financial Forensics Body of Knowledge“, John Wiley \& Sons, Inc., Hoboken, USA 460.

6. Lyman $M D(2011)$ Criminal Investigation - The Art and the Science, Sixth Edition“, Prentice Hall, Pearson Education, Inc., Boston, USA 470-471.

7. Pasco GA (2013) Criminal Financial Investigations - The Use Of Forensic Accounting Techniques And Indirect Methods of Proof, Second Edition", CRC Press, Taylor \& Francis Group, Boca Raton, USA 1: 19

8. Lessambo FI (2018) Auditing, Assurance Services, and Forensics - A Comprehensive Approach", Palgrave Macmillan, Springer International Publishing AG, Cham, Switzerland 454-455.

9. Zack GM(2013) Financial Statement Fraud - Strategies for Detection and Investigation“, John Wiley \& Sons, Inc Hoboken USA 209.

10. Skramstad E (2011) Teaming with Forensic Accounting Investigators" in Golden, TW Skalak, SL. Clayton, MM Pill JS (eds): A Guide to Forensic Accounting Investigation, Second Edition“, PricewaterhouseCoopers, John Wiley \& Sons, Inc. Hoboke USA 115.

11. Miller FR, Marston DL(2011) Building a Case: Gathering and Documenting Evidence " in Golden, T. ; Skalak SL; Clayton, MM Pill, J. S. (eds): A Guide to Forensic Accounting Investigation, Second Edition"PricewaterhouseCoopers, John Wiley \& Sons, Inc., Hoboke, USA 175.

12. Okuda MM, Stephenson FH (2015) A Hands-On Introduction to Forensic Science - Cracking the Case“, CRC Press, Taylor \& Francis Group, USA 11.

13. Telpner Z, Mostek M(2003) Expert Witnessing in Forensic Accounting - A Handbook for Lawyers and Accountants" CRC Press LLC, Boca Raton, USA $1-2$ 